\title{
Differential Expression of Pentraxin 3 in Fibroblasts from Patients with Major Depression
}

\author{
Richard C Shelton*,',3, Shan Liang', Peng Liang', Amitabha Chakrabarti', D Hal Manier' and Fridolin \\ Sulser ${ }^{1,3}$ \\ 'Department of Psychiatry, Vanderbilt University Medical Center, Nashville, TN, USA; ${ }^{2}$ Department of Cancer Biology, Vanderbilt University \\ Medical Center, Nashville, TN, USA; ${ }^{3}$ Department of Pharmacology, Vanderbilt University Medical Center, Nashville, TN, USA
}

\begin{abstract}
In this study, differential display technology was used to compare gene expression in cultured fibroblasts from patients with major depression, melancholic subtype vs nonmelancholic depressives and normal volunteer controls. Genes differentially expressed in depressives and normals included an overexpressed 269 bp sequence tag showing 95\% identity with the Homo sapiens long pentraxin 3 (PTX3) gene sequence in the $3^{\prime}$ noncoding region. The $269 \mathrm{bp}$ complimentary DNA probe hybridized with the $1.9 \mathrm{~kb}$ PTX3 mRNA. The densitometric analysis of slot blots showed that the mean steady-state mRNA level of PTX3 was 3.5-fold higher in the melancholic group as compared to that in normal controls and in nonmelancholic depressives ( $n=8$, all groups). Incubation experiments were then conducted: confluent fibroblasts from melancholics and normal volunteers were incubated with isoproterenol I $\mu \mathrm{M}$, dexamethasone (DEX) $500 \mathrm{nM}$, and interleukin I $\beta$ (IL-I $\beta) 50 \mathrm{ng} / \mathrm{ml}$, for 0, 0.5, I, 4, and $24 \mathrm{~h}$. mRNA was isolated and quantitated using Northern blot analysis. Isoproterenol produced no significant change in PTX3 expression; DEX produced a significant increase at 4 and $24 \mathrm{~h}$; IL-I $\beta$ induced an increase in both the groups that peaked at $4 \mathrm{~h}$, declining to near basal levels at $24 \mathrm{~h}$. There were no differences between melancholics or controls in mean change or maximum response with either DEX or IL-I $\beta$. The results are consistent with the reported effects of IL-I $\beta$ on PTX3 expression in mouse brain. The results are of potential importance because PTX3 is a member of the long pentraxin subfamily of acute-phase proteins, which is inducible by $\mathrm{IL}-\mathrm{I} \beta$, and may play roles in neuroimmunity and neuroprotection. Neuropsychopharmacology (2004) 29, 126-132, advance online publication, 5 November 2003; doi: 10.1038/sj.npp. 1300307
\end{abstract}

Keywords: differential gene expression; human fibroblasts; major depression; pentraxin 3; cytokines; acute-phase proteins

\section{INTRODUCTION}

Due to the inaccessibility of human brain tissue, peripheral cells including lymphocytes and fibroblasts have been useful to probe inherited biochemical lesions in man (Edelstein and Breakefield, 1980). Human fibroblasts as non-neuronal tissue express genes encoding proteins involved in monoaminergic-G-protein-coupled transduction cascades similar to the expression in neuronal tissue, for example, beta adrenoreceptors, $5 \mathrm{HT}_{2 \mathrm{~A}}$ receptors, and G-proteins. Using human fibroblasts, our group has demonstrated abnormalities in the beta adrenoceptor-cyclic AMP-mediated activation of protein kinase A (PKA) and phosphorylation of the transcription factor cyclic AMP response element-binding protein (CREB) in patients with major depression, melancholic subtype, relative to normal

*Correspondence: Dr RC Shelton, Department of Psychiatry, Vanderbilt University Medical Center, 150021 st Avenue, South, Suite 2200, Nashville, TN 3721 I, USA, Tel.: + I (6I5) 343 9669, Fax: + I (6I5) 343 7868, E-mail: richard.shelton@vanderbilt.edu

Received 05 December 2002; revised 14 July 2003; accepted 08 August 2003

Online publication: 20 August 2003 at http://www.acnp.org/citations/ Npp0820020448/default.pdf volunteers and nonmelancholic depressives (Shelton et al, 1996, 1999; Manier et al, 1996, 2000). These findings are similar to the results from other investigators, including a decrease in the putative binding of cyclic AMP to PKA in post-mortem brains of patients with bipolar disorder (Rahman et al, 1997). Of particular relevance are the findings of Dwivedi et al $(2000,2002)$, who showed that persons who died by suicide with a history of a diagnosis of MDD (but not those without) had reduced prefrontal $\left[{ }^{3} \mathrm{H}\right]$ cyclic AMP binding (reduced $B_{\max }$ but normal $K_{\mathrm{D}}$ ) and lower PKA activity $v s$ normal controls.

Altered gene expression has been hypothesized to be a factor in the vulnerability to mood disorders (Rossby et al, 2000; Duman et al, 2000). Given the fact that phosphorylated CREB (CREB-P) regulates the expression of genes containing CRE elements, we have hypothesized that fibroblasts with decreased PKA-CREB-P activity from depressed patients would show alterations in gene expression relative to those from controls. Accordingly, we have used differential display (Liang and Pardee, 1992) to contrast gene expression patterns in cultured fibroblasts from patients with major depression with melancholia $v s$ normal volunteers and nonmelancholic depressives. The samples from patients with melancholia had previously 
been shown to have reduced PKA activity and CREB phosphorylation; the nonmelancholics and normal volunteers all had PKA-CREB-P within the normal range previously reported (Shelton et al, 1999; Manier et al, 2000). A strength of differential display is that it is capable of detecting both known and novel genes and does not require an a priori hypothesis.

This report describes the differential expression of the Homo sapiens pentraxin 3 (PTX3) gene (Breviario et al, 1992 ) in these samples, as well as results of incubations with isoproterenol, dexamethasone (DEX), and interleukin $1 \beta$ (IL-1 $\beta)$. PTX3 belongs to the subfamily of long pentraxins with a C-terminal 203 amino-acid sequence comparable to the short pentraxins (eg C-reactive protein) and an $\mathrm{N}$ terminal 178 amino-acid unrelated portion (Breviario et al, 1992; Goodman et al, 1996; Bottazzi et al, 1997). The exact function of PTX3 remains unknown. The expression of PTX3 is inducible by IL- $1 \beta$ and tumor necrosis factor alpha $(\mathrm{TNF} \alpha)$ in the brain (Polentarutti et al, 2000), endothelial cells (Breviario et al, 1992), and fibroblasts (Lee et al, 1993; Lee and Masson, 1993; Diaz et al, 2001). This may be significant given the extensive literature relating depression and immune dysfunction (Leonard, 2000); depressed patients have been shown to have significant elevations of cerebrospinal fluid levels of IL-1 $\beta$, IL-6, and TNF- $\alpha$, effects that are antagonized by antidepressants (Levine et al, 1999; Castanon et al, 2002). Although the exact function of PTX3 remains unknown, it has been shown to associate with apoptotic cells. Ravizza et al (2001) have shown that PTX3 immunoreactivity is induced in the rat forebrain by seizure activity. However, expression beyond $18 \mathrm{~h}$ is only enhanced in areas of neurodegeneration. The authors suggest that this may be a result of a neuroprotective role for PTX3 in brain immune and inflammatory response. These results indicate that PTX3 may have an important role in mediating central and peripheral immunoreactivity.

\section{PATIENTS, MATERIALS, AND METHODS}

\section{Collection and Culturing of Human Fibroblasts}

All procedures involving human subjects were conducted after written informed consent was obtained. All procedures were conducted according to the Declaration of Helsinki of 1975. Strict confidentiality was maintained for all participants. The methods used for this project were similar to those previously described (Shelton et al, 1996; Liang et al, 2001). In brief, skin biopsies for fibroblast cultures were obtained from persons with major depression, melancholic subtype $(n=8$; seven females), major depression not meeting the diagnostic criteria for melancholia $(n=8$, seven females), and normal volunteers ( $n=8$; six females); mean age $44.8(\mathrm{SD}=13.6), 35.7 \quad(\mathrm{SD}=12.1)$, and 37.7 $(\mathrm{SD}=12.3) \quad(\mathrm{ANOVA}=\mathrm{NS})$, respectively. Subjects were evaluated using the Structured Clinical Interview for DSMIV (First et al, 1996). A second diagnostic interview was conducted by a senior clinician; diagnostic assignment, including subtyping, was made based on a consensus between the two interviewers. All the patients all had a principal diagnosis of major depression; secondary diagnoses were allowed. However, no patient had bipolar disorder or a current or past history of psychotic disorder.
Normal volunteer controls were free of Axis I mental disorder by DSM-IV (American Psychiatric Association, 1994). Skin samples were taken via punch biopsy; fibroblast cultures were grown in Dulbecco's modified Eagle medium (Life Technologies, Grand Island, NY) containing 10\% fetal bovine serum (Hyclone, Logan, UT) at $37^{\circ} \mathrm{C}$, in a humidified atmosphere containing $5 \% \mathrm{CO}_{2}$ until confluent (approximately 3 weeks), as previously described (Manier et al, 1996, 2000).

\section{RNA Isolation, Reverse Transcription, and Differential Display}

Confluent fibroblasts from cultures were lysed with TRI Reagent (Molecular Research Center, Inc., Cincinnati, OH, USA). RNA was isolated and purified as previously described (Liang et al, 2001). Three reverse transcriptions of each RNA sample were performed. Differential display was conducted using RNAimage Kits (GenHunter Corp., Nashville, TN, USA), ultimately utilizing 80 arbitrary upstream 13mer primers, each in combination with the three one-base anchored primers (a total of 240 reactions) to display approximately $96 \%$ of the genes expressed in the fibroblasts. The bands containing apparently differentially expressed genes (cDNAs) were excised, reamplified, and subcloned via the PCR-TRAP cloning system (GenHunter Corp., Nashville, TN, USA), and sequenced in the Vanderbilt University DNA-sequencing core facility (Liang et al, 2001). A total of 18 genes were differentially expressed.

\section{Riboprobe Preparation}

A double-stranded DNA template containing the reamplified band, containing a T7 phage promoter at the $5^{\prime}$ end and an SP6 phage promoter at the $3^{\prime}$ end was produced via PCR in an amplification reaction containing $2 \mu \mathrm{l}(2 \mu \mathrm{M})$ each of T7-Lgh and Sp6-Rgh (GenHunter) in $10.2 \mu 1$ nuclease-free water, $2.0 \mu \mathrm{l} 10 \times$ PCR buffer, $1.6 \mu \mathrm{l} \alpha$-dNTPs $(250 \mu \mathrm{M}), 2.0 \mu \mathrm{l}$ of the PCR-TRAP plasmid containing the DNA sequence, and $0.2 \mu \mathrm{l}$ Amplitaq. The PCR reaction was subsequently checked by visualizing the amplified band in a $2 \%$ agarose gel.

Synthesis of a radiolabeled antisense PTX3 RNA probe (riboprobe) for Northern blot analysis was performed with a Strip-EZ RNA SP6/T7 kit (Ambion Inc., Austin, TX), using PTX3 cDNA cloned from differential display (AAGCTTT GGTCAGAGATGAATTTTA CATTGGAAGAATAACAAAA TAAGATTTGTTGTCCATTGTTCATTGTTATTGGGTATGC ACCTTATTACAAAAAAAAGATGAAACATATTTATACTG CAAGGTGACTTAACAACTATAAATGTAGTTTATGTGTG ATAATCGAATGTCACGTTTTTGAGAAGATAGTCATATAA GTTATATTGCAAAAGGGATTTGTATTAATTTAAGACTA TTTTTGTAAAGCTCTACTGTAAATAAAATATTTTATAAA AAAAAAAAGCTT). The PTX cDNA was first directionally cloned into PCR-TRAP cloning vector (GenHunter Corp., Nashville, TN) and amplified using SP6 and T7 primers (GenHunter Corp., Nashville, TN) adjacent to the cloning site. The resulting PTX3 cDNA template was gel purified and used as a template. The antisense RNA synthesis was conducted in a final volume of $20 \mu \mathrm{l}$ containing $7 \mu \mathrm{l}$ nuclease-free water, $1 \mu \mathrm{g}$ DNA template, $2 \mu \mathrm{l} 10 \times$ transcription buffer, $1 \mu \mathrm{l} 10 \mathrm{mM}$ ATP, $1 \mu \mathrm{l} 10 \mathrm{mM}$ CTP, $1 \mu \mathrm{l}$ 
$10 \mathrm{mM}$ GTP, $5 \mu \mathrm{l}$ [a-32P]-UTP $(12.5 \mu \mathrm{M})$, and $2 \mu \mathrm{l}$ Sp6 polymerase. The reagents were mixed thoroughly by fingertapping, followed by brief centrifugation. The reaction was incubated for $60 \mathrm{~min}$ at $37^{\circ} \mathrm{C}$. Template DNA was subsequently removed by the addition of $1 \mu \mathrm{l}$ RNase-free DNase $1(2 \mathrm{U} / \mu \mathrm{l})$. The reactants were mixed by fingertapping, microfuged briefly, and incubated at $370^{\circ} \mathrm{C}$ for $15 \mathrm{~min}$. Unincorporated ribonucleotides were removed with G-50 spin columns (Boehringer Mannheim Corp., Indianapolis, IN).

\section{Northern Blot and Slot Blot Analysis}

Fibroblast RNA $(20 \mu \mathrm{g})$ was resolved by electrophoresis through $2.2 \mathrm{M}$ formaldehyde/1\% agarose gel in MOPS buffer (20 mM MOPS [3-( $N$-morpholino)propanesulfonic acid], pH 7.0, $10 \mathrm{mM}$ sodium acetate, $1 \mathrm{mM}$ EDTA) in gelloading buffer containing ethidium bromide (GenHunter, Nashville TN) for about $3 \mathrm{~h}$ at $50 \mathrm{~V}$. The gel was then digitally UV-photographed along with a fluorescent ruler using an AlphaImager 2000 (Alpha InnoTech Corporation, San Leandro, CA) for marking the positions of gel wells, $18 \mathrm{~S}$ RNA, and $28 \mathrm{~S}$ RNA. The RNA was transferred from the gel to a nylon membrane using the Turbo blotter Rapid Downward Transfer System (Schleicher \& Schuell, Keene, NH). Transferred RNA was immobilized on the nylon membrane by UV crosslinking in Stratalinker UV Crosslinker (Stratagene, La Jolla, CA). Prehybridization $(2 \mathrm{~h})$ and hybridization $(3 \mathrm{~h})$ were conducted in $30 \mathrm{ml}$ of Rapid-Hyb solution at $70^{\circ} \mathrm{C}$ (Amersham Pharmacia Biotech, Piscataway, NJ). After prehybridization, the membrane was hybridized with $2.5 \times 10^{7} \mathrm{cpm}$ riboprobe (see Riboprobe Preparation) and washed two times (15 min each time) in $150 \mathrm{ml} 2 \times \mathrm{SSC}, 0.1 \% \mathrm{SDS}$ at room temperature, followed by washing two times (15 min each time) in $150 \mathrm{ml} 0.1 \mathrm{SSC}, 0.1 \%$ SDS at $70^{\circ} \mathrm{C}$. The membrane was subsequently exposed overnight to a Kronex 10T Medical X-Ray film (Sterling Diagnostic Imaging, Inc., Newark, DE).

A measure of $5 \mu \mathrm{g}$ of total fibroblast RNA from $(n=8$ each) melancholic depressives, nonmelancholics, and normal volunteer controls (in nuclease-free water) was combined with $8 \mu \mathrm{l} 37 \%$ formaldehyde and $12 \mu \mathrm{l} 20 \times$ SSC (Gibco BRL Life Technologies,Grand Island, NY) and heatdenatured for $15 \mathrm{~min}$ at $60^{\circ} \mathrm{C}$. Each denatured sample was then mixed with $5 \mu \mathrm{l}$ ethidium bromide solution $(12 \mu \mathrm{l}$ of stock $10 \mathrm{mg} / \mathrm{ml}$ (Gibco BRL Life Technologies, Grand Island, NY) $+88 \mu \mathrm{l}$ of $6 \times$ SSC) and diluted to a total volume of $400 \mu \mathrm{l}$ with $10 \times$ SSC. The samples were subsequently applied to a GeneScreen Plus membrane (DuPont, Boston, MA) via a slot blot apparatus (PR 600, Hoefer Scientific Instruments, San Francisco, CA) with low vacuum. Prior to loading, the membrane was soaked in nuclease-free water followed by $10 \times$ SSC, and placed on two sheets of $3 \mathrm{MM}$ paper prewetted with $10 \times$ SSC. After loading, the wells were washed with $400 \mu 10 \times$ SSC. The membrane was then removed from the slot blot apparatus and placed in a Stratalinker UV Crosslinker (Stratagene, La Jolla, CA) to immobilize the RNA to the membrane. After crosslinking, the membrane was air-dried for $30 \mathrm{~min}$, pencil-marked as necessary to track for the relative positions of samples, and digitally UV-photographed using
AlphaImager 2000 (Alpha InnoTech Corporation, San Leandro, CA). The AlphaImager was then used to calculate the band intensities of the ethidium bromide-stained RNA molecules in each band from this digital picture of the membrane. The intensities obtained with ethidium bromide staining of the RNA molecules bound to the membrane in the different slots were used to normalize the PTX3 slot blot band intensities for slot-to-slot loading variation (Duhl et al, 1992). The membrane was then placed in prehybridization solution. Prehybridization $(2 \mathrm{~h})$ and hybridization $(3 \mathrm{~h}$ ) were conducted in $30 \mathrm{ml}$ of RapidHyb solution (Amersham Pharmacia Biotech, Piscataway, $\mathrm{NJ})$ at $70^{\circ} \mathrm{C}$. After prehybridization, the membrane was hybridized with $2.5 \times 10^{7} \mathrm{cpm}$ riboprobe (see Riboprobe Preparation above) and washed two times (15 min each time) in $150 \mathrm{ml} 2 \times \mathrm{SSC}, 0.1 \% \mathrm{SDS}$ at room temperature, followed by washing two times (15 min each time) in $150 \mathrm{ml} 0.1 \mathrm{SSC}, 0.1 \%$ SDS at $70^{\circ} \mathrm{C}$. The membrane was subsequently exposed overnight to Kronex $10 \mathrm{~T}$ Medical XRay film (Sterling Diagnostic Imaging, Inc., Newark, DE). The autoradiograph was scanned with an AlphaImager 2000 (Alpha InnoTech Corporation, San Leandro, CA) to determine band densities. Student's $t$-test was used to determine the significance.

\section{Incubations}

Since a factor contained in serum could have been responsible for the increased PTX3 expression, fibroblast cultures from melancholics and normal volunteers were exposed for $18 \mathrm{~h}$ to reduced serum $(0.5 \%)$ prior to the incubations. Time-response curves were generated with in situ incubations of the following reference compounds conducted for $0,0.5,1,4$, and $24 \mathrm{~h}$ : isoproterenol $1 \mu \mathrm{M}$ (Sigma Chemical Co., St Louis, MO); IL-1 $\beta \quad 50 \mathrm{ng} / \mathrm{ml}$ (Calbiochem, La Jolla, CA); and DEX $500 \mathrm{nM}$ (Sigma Chemical Co., St Louis, MO). RNA was then extracted and mRNA quantitated by Northern Blot analysis as described earlier. The concentrations of isoproterenol, DEX, and IL- $1 \beta$ chosen for incubation experiments were estimated to yield maximal response, based on previous experiments conducted by our laboratory and others for each compound (Breviario et al, 1992; Manier et al, 2000; Pariante et al, 2001); however, the maximal response was confirmed by constructing dose-response curves.

\section{RESULTS}

One of the differentially expressed cDNA bands was excised, the cDNA subcloned and sequenced, yielding a nonambiguous $269 \mathrm{bp}$ sequence tag (Figure 1). An NCBI GenBank BLAST search (http://www.ncbi.nlm.nih.gov) indicated that this tag is $\sim 95 \%$ identical with the human PTX3 gene sequence (nucleotides 1548-1816) in the $3^{\prime}$ noncoding region (Breviario et al, 1992). Utilizing Northern blot analysis, the riboprobe hybridized with an approximately $1.9 \mathrm{~kb}$ mRNA with a molecular weight matching PTX3 mRNA $(1.86 \mathrm{~kb})$. Since the probe hybridized with only one band, slot blots were utilized to confirm that the differences were due to differential expression and not to a PCR artifact. The mean basal PTX3 mRNA expression in the melancholic 


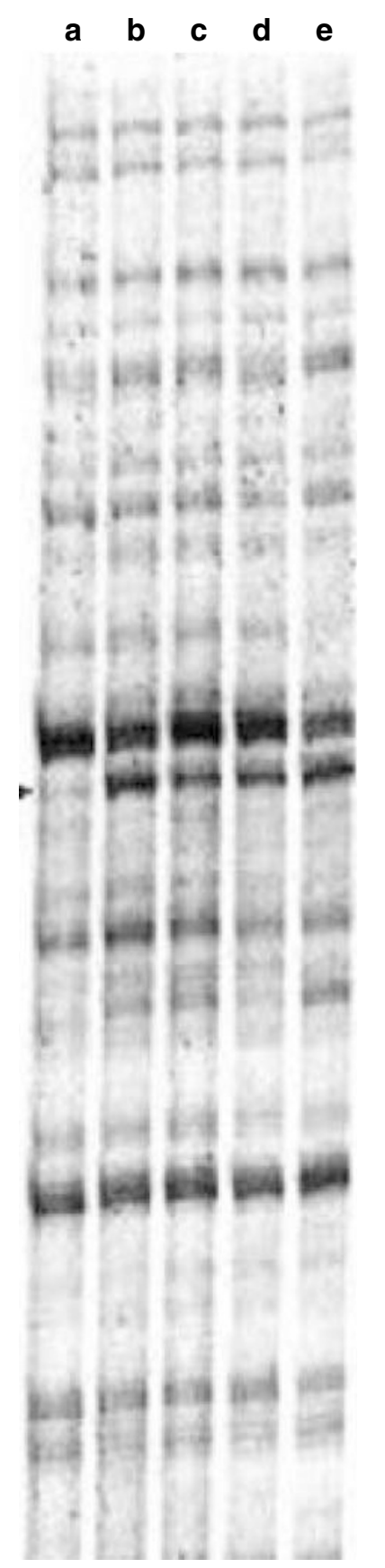

Figure I Autoradiogram displaying cDNA bands amplified from human fibroblast RNA utilizing $\mathrm{HAP}_{22}$ as an arbitrary primer and $H T_{1}, \mathrm{C}, H T_{1,} \mathrm{G}$, and $\mathrm{HT}_{1} \mathrm{~A}$ as anchor primers. cDNAs reverse transcribed from mRNA isolated from the fibroblasts of one normal subject (a) and four patients with a diagnosis of major depression (b-e) were used as templates for amplification by PCR. The cDNA corresponding to the differentially expressed band was excised from the gel, cloned, and sequenced, as described in Patients, materials and methods.

patient group was approximately 3.5 -fold higher than that in normal controls or nonmelancholics (Figure 2).

The results of the incubation experiments are depicted in Figure 3. Reduced serum decreased the expression of PTX3 in samples from both controls and melancholic depressives (mean decrease of $65 \%$ and $79 \%$, respectively). Response to $1 \mathrm{~L}-1 \beta$ occurred in a time-responsive fashion, with a peak

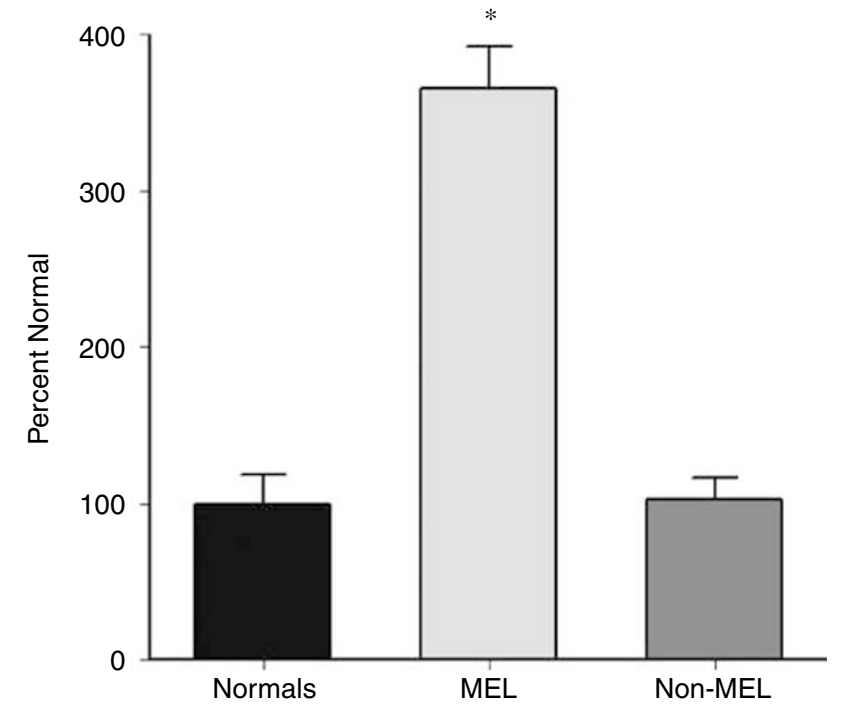

Figure 2 Densitometric analysis of PTX3 data. Riboprobe preparation and hybridization were performed as described in Patients, materials and methods. Total RNA from the fibroblasts of eight normal volunteers (black bar $\mathbf{n}$ ) was compared with that of eight patients with major depression, melancholic subtype (MEL) (light gray bar -), and eight patients with major depression without melancholia (dark gray bar $\square$ ) for the expression of PTX3 mRNA. The autoradiographs were scanned with an LKB Ultroscan enhanced laser densitometer. Normalization of the band intensities for loading variation was done using the scanning data of ethidium bromide stains of the bands, as described in Patients, materials and methods. The scanning data are expressed as per cent of control values (normal subjects) \pm SEM; ${ }^{*} p<0.001$.

at $4 \mathrm{~h}$ (mean increase, depressed $=501.1 \%$, controls $=774.9 \%$ ), declining to near basal levels at $24 \mathrm{~h}$, in a fashion similar to that shown in the brain (Polentarutti et al, 2000). DEX produced small but significant increases at $4 \mathrm{~h}$ (depressed $=180.4 \%$, controls $=220.6 \%$ ), which were sustained at $24 \mathrm{~h}$ (depressed $=177.8 \%$, controls $=227.1 \%$ ). Isoproterenol did not produce any significant change in PTX3 at any time point. There were no differences between groups in the proportional changes in PTX3 in any of the incubation experiments.

Since the maximum response occurred for IL- $1 \beta$ and DEX occurred at $4 \mathrm{~h}$, a dose-response curve was generated at that time point to establish that, in fact, a maximal concentration had been used. Confluent fibroblasts were incubated with concentrations of IL- $1 \beta$ of $0,2.5,25,50$, and $100 \mathrm{ng} / \mathrm{ml}$; a maximum response was achieved at $50 \mathrm{ng} / \mathrm{ml}$, yielding an $\mathrm{EC}_{50}$ concentration of $1.06 \mathrm{ng} / \mathrm{ml}$. Similarly, a doseresponse curve was generated for DEX at doses of 0,25 , 250,500 , and $1000 \mathrm{nmol}$; this yielded a maximal response at $250 \mathrm{nmol}$ and an $\mathrm{EC}_{50}$ concentration of $4.90 \mathrm{nM}$. Isoproterenol yielded no effect in doses up to $10 \mu \mathrm{M}$.

\section{DISCUSSION}

The present results indicate that there is a 3.5 -fold greater basal expression of the H. sapiens PTX3 gene in fibroblasts cultured from patients with major depression, melancholic subtype with low PKA activity $v s$ normal controls and nonmelancholics. It remains to be elucidated whether increased cellular production of IL-1 $\beta$ or TNF- $\alpha$, increased 


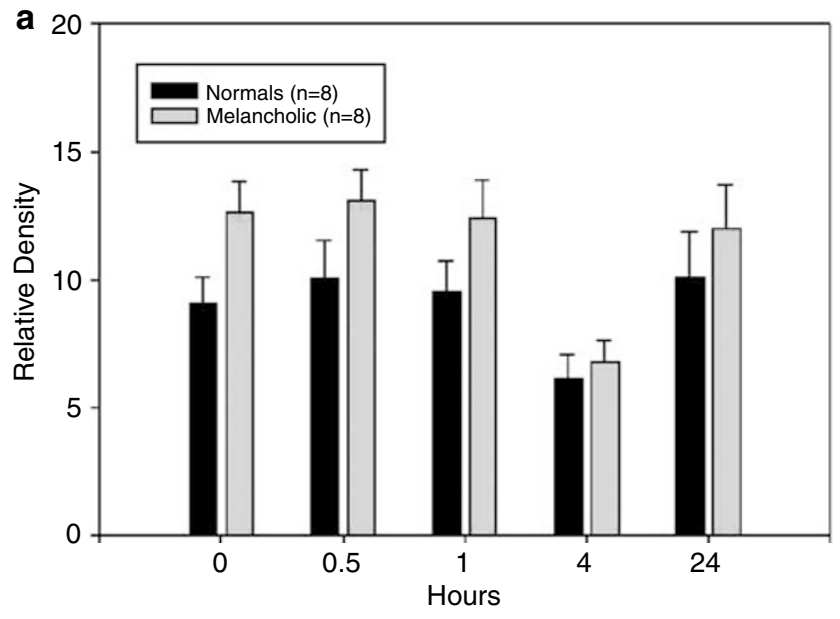

b
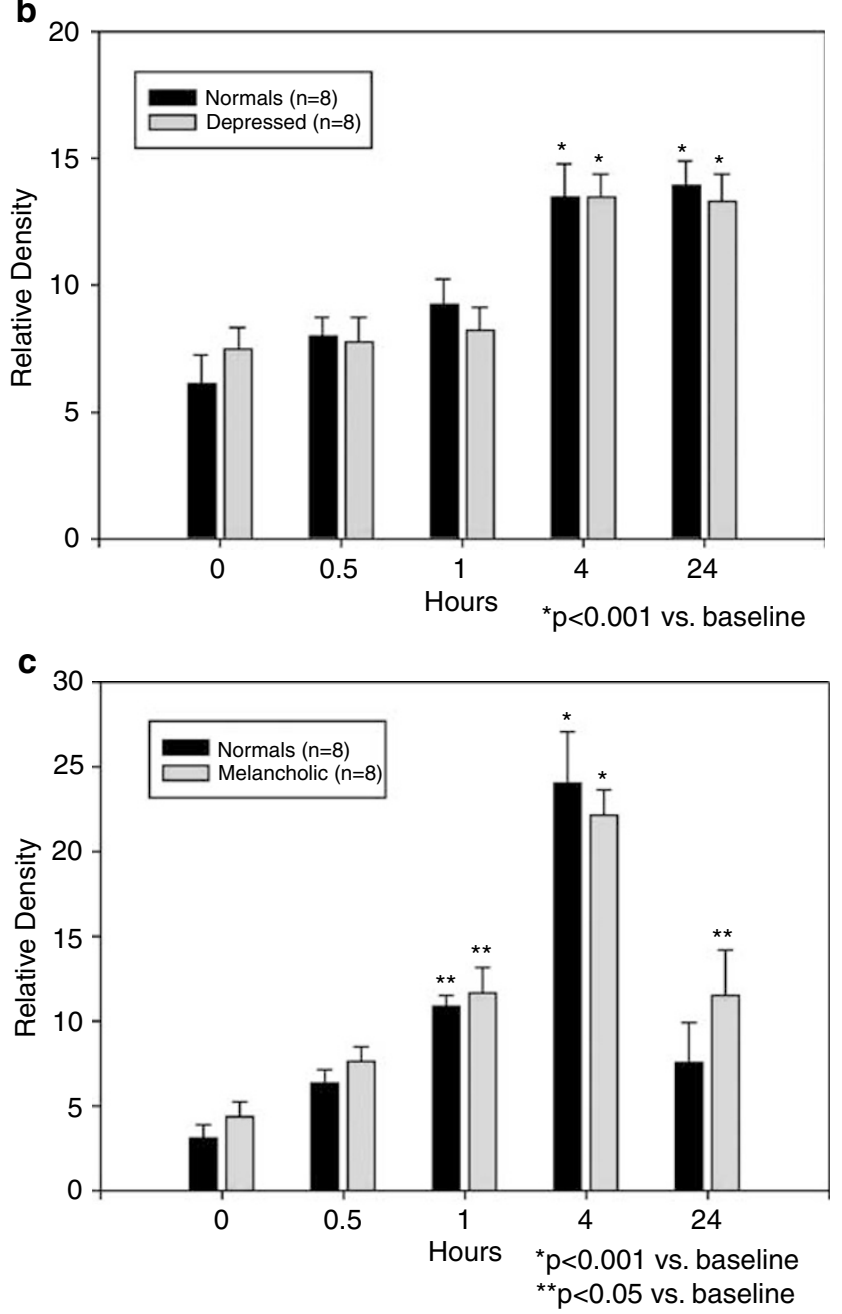

Figure 3 The effects of incubations on PTX3 expression. Confluent fibroblast cultures from normal volunteers (black bars ) and persons with major depression, melancholic subtype (gray bars -$)(n=8$ per group) were incubated for $0.5, I, 4$, and $24 \mathrm{~h}$ with isoproterenol I $\mu \mathrm{M}$ (a), DEX $500 \mathrm{nM}$ (b), and $\mathrm{IL}-\mathrm{I} \beta 50 \mathrm{ng} / \mathrm{ml}$ (c), after $18 \mathrm{~h}$ of reduced serum exposure. PTX3 expression was determined as described in Patients, materials and methods, and compared with the basal expression in each experiment. The autoradiograph was scanned with an LKB Ultroscan enhanced laser densitometer. Normalization of the band intensities for loading variation was done using the scanning data of ethidium bromide stains of the bands, as described in Patients, materials and methods. The scanning data are expressed as normalized relative densities \pm SEM; $* p<0.00$ I, $* * * 0.05$ (vs 0 h). basal expression of the gene itself, or alterations in another regulatory factor could explain the altered expression of PTX3 in human fibroblasts in culture.

The incubation of fibroblast cultures with isoproterenol did not produce a significant change in PTX3 expression. Incubation with isoproterenol was conducted since the cells chosen for study came from melancholic depressed patients, who had been previously shown to have reduced activity of isoproterenol-stimulated PKA activity relative to normal controls. However, no clear relationship between isoproterenol stimulation and PTX3 gene expression was shown. This suggests that the altered expression of PTX3 is not directly related to decreased PKA activity; however, factors regulated by genes linked to the PKA-CREB-CRE transduction cascade could be responsible for the effect.

Alternatively, the incubation of fibroblast cultures with IL-1 $\beta$ produced a time-dependent increase in PTX3 expression over $4 \mathrm{~h}$ that declined to near baseline levels at $24 \mathrm{~h}$. The maximal increase in expression of PTX3 at $4 \mathrm{~h}$ was about $500 \%$ for melancholics. The change in expression did not significantly differ between the two patient groups and controls; it is possible that significant differences could be demonstrated with a larger sample. Future experiments with an enlarged sample will need to be conducted to test whether there are significant differences between groups in maximal response to IL- $1 \beta$. Nonetheless, these data are consistent with the response to IL- $1 \beta$ in CNS (Polentarutti et al, 2000), and support the identity of the expressed species as PTX3. However, our longer-term data suggest a decrease in the responsiveness to IL- $1 \beta$ over time, suggesting a counter-regulatory response. This has not been described previously, to our knowledge. Abnormalities of cytokine activity in melancholia have been described (Anisman et al, 1999). However, the differences in PTX3 expression in the present experiment are not explainable by dissimilarities in plasma interleukins, since the fibroblasts from patients and controls were cultured in the same media. This would suggest that a factor intrinsic to the cells themselves would account for the findings. In addition, the incubation experiment indicated that PTX3 response to IL$1 \beta$ was downregulated at $24 \mathrm{~h}$; therefore, increased cellular expression of IL-1 $\beta$ seems unlikely to be the cause of differences in PTX3 expression. Consequently, factors other than IL-1 $\beta$ are likely to account for the effect and need to be explored further.

DEX also produced a significant enhancement of expression of PTX3 at $4 \mathrm{~h}$, which was sustained at $24 \mathrm{~h}$. As far as we are aware, this is the first demonstration of an enhancement of PTX3 expression, including longer-term induction, in any tissue type by glucocorticoids (Agnello et al, 2000). This is consistent with the effects of glucocorticoids on other acute-phase proteins, however (Baumann et al, 1991). Alternatively, Agnello et al (2000) showed that experimental autoimmune encephalomyelitis elevated PTX3 expression and DEX administration abolished the increase in PTX3. The disparity in findings between experiments may be a result of differences in tissue type or variation in experimental conditions; in our study, DEX was administered to normal cells, while Agnello et al (2000) examined the effect of DEX administration on the PTX3 induction that, presumably, was a result of inflammation. 
Although there was an increase in basal expression in PTX3 when cells were incubated with fetal calf serum, there was a substantial reduction in expression in the reducedserum medium. This suggests that a serum factor could be associated with the difference in expression. The differential expression does not seem to be directly associated with either IL-1 $\beta$ or DEX; although both significantly increased PTX3 expression, there was no difference seen between patients and controls. Therefore, another factor that regulates the expression of the gene may be involved. However, the demonstration of an increase in PTX3 with both IL- $1 \beta$ and DEX is similar to that seen in the CNS, and supports a role for PTX3 in cellular stress response.

The findings of this study were only in fibroblasts, a peripheral cell type that may or may not show gene expression homology with brain. Furthermore, the number of participants was small; replication in a larger sample is needed. As noted earlier, the ultimate function of PTX3 is unknown, although it is associated with neuronal apoptosis and may have a neuroprotective role (Ravizza et al, 2001). If the increased expression of PTX3 is confirmed in the brains of patients with depression, the finding will add to a growing body of evidence, suggesting neuroendocrineimmune dysfunction in melancholia (Miller et al, 1999; O'Connor et al, 2000).

\section{ACKNOWLEDGEMENTS}

The present studies were supported by NIH grants $\mathrm{MH}$ 01741, MH-52339, and by a grant-in-aid from Wyeth-Ayerst Research. Dr Chakrabarti is the recipient of a NARSAD Young Investigator Award. The data were presented at the Annual Meeting of the American College of Neuropsychopharmacology, Waikaloa, HI, 2001. We thank Mrs Gloria Hopkins and Waverly Demers for the preparation and typing of the manuscript and Dr Elaine Sanders-Bush for helpful discussions and expert advice.

\section{REFERENCES}

Agnello D, Carvelli L, Muzio V, Villa P, Bottazzi B, Polentarutti N et al. (2000). Increased peripheral benzodiazepine binding sites and pentraxin 3 expression in the spinal cord during EAE: relation to inflammatory cytokines and modulation by dexamethasone and rolipram. J Neuroimmunol 109: 105-111.

American Psychiatric Association (1994). Diagnostic and Statistical Manual of Mental Disorders 4th edn American Psychiatric Press: Washington, DC.

Anisman H, Ravindran AV, Griffiths J, Merali Z (1999). Endocrine and cytokine correlates of major depression and dysthymia with typical or atypical features. Mol Psychiatry 4: 182-188; 1999.

Baumann H, Jahreis GP, Morella KK, Won KA, Pruitt SC, Jones VE et al (1991). Transcriptional regulation through cytokine and glucocorticoid response elements of rat acute phase plasma protein genes by C/EBP and JunB. J Biol Chem 266: 20390-20399.

Bottazzi B, Vouret-Craviari V, Bastone A, De Gioia L, Matteucci C, Peri G et al (1997). Multimer formation and ligand recognition by the long pentraxin PTX3. Similarities and differences with the short pentraxins C-reactive protein and serum amyloid $\mathrm{P}$ component. J Biol Chem 272: 32817-32823.

Breviario F, d'Aniello EM, Golay J, Peri G, Bottazzi B, Bairoch A et al (1992). Interleukin-1-inducible genes in endothelial cells: cloning of a new gene related to C-reactive protein and serum amyloid P component. J Biol Chem 267: 22190-22197.

Castanon N, Leonard BE, Neveu PJ, Yirmiya R (2002). Effects of antidepressants on cytokine production and actions. Brain Behav Immun 16: 569-574.

Diaz AAM, Goodman AR, Santos JLD, Gomez RN, Altmeyer A, Bozza PT et al (2001). TSG-14 transgenic mice have improved survival to endotoxemia and to CLP-induced sepsis. J Leucoc Biol 69: 928-936.

Duhl DM, Gillespie DD, Sulser F (1992). Ethidium bromide fluorescence of $28 \mathrm{~S}$ ribosomal RNA can be used to normalize samples in Northern or dot blots when analyzing small druginduced changes in specific mRNA. J Neurosci Methods 42: 211-218.

Duman RS, Malberg J, Nakagawa S, D’Sa C (2000). Neuronal plasticity and survival in mood disorders. Biol Psychiatry 48: 732-739.

Dwivedi Y, Conley R, Roberts RC, Tamminga CA, Pandey GN (2002). Reduced $\left[{ }^{3} \mathrm{H}\right]$ cyclic AMP binding sites and PKA activity in the prefrontal cortex of suicide subjects. Am J Psychiatry 159: 66-73.

Dwivedi Y, Rizavi H, Conley RR, Roberts RC, Tamminga CA, Pandey GN (2000). Decreased CREB, phospho-CREB and protein kinase A catalytic $\beta$ subunit expression in the prefrontal cortex of depressed suicide subjects. Int J Neuropsychopharmacol 3(Suppl 1): S207.

Edelstein SB, Breakefield XO (1980). Physico-chemical methodologies. In: Hanin I, Koslow SH (eds) Psychiatry Research. Raven Press: New York. pp 200-243.

First MB, Spitzer RL, Gibbon M, Williams JBW (1996). Structured Clinical Interview for Axis I DSM-IV Disorders (Version 20). Biometrics Research Department, New York State Psychiatric Institute: New York.

Goodman AR, Cardozo T, Abagyan R, Altmeyer A, Wisniewski HG, Vilcek J (1996). Long pentraxins: an emerging group of proteins with diverse functions. Cytokine Growth Factor Rev 7: 191-202.

Lee GW, Lee TH, Vilcek J (1993). TSG-14, a tumor necrosis factor and IL-1-inducible protein, is a novel member of the pentaxin family of acute phase proteins. J Immunol 150: 1804-1812.

Lee KAW, Masson N (1993). Transcriptional regulation by CREB and its relatives. Biochem Biophys Acta 1174: 221-233.

Leonard B (2000). Stress, depression and the activation of the immune system. World J Biol Psychiatry 1: 17-25.

Levine MA, Barak Y, Chengappa KNR, Rapoport A, Rebey M, Barak V (1999). Cerebrospinal cytokine levels in patients with acute depression. Neuropsychobiology 40: 171-176.

Liang P, Pardee AB (1992). Differential display of eukaryotic messenger RNA by means of the polymerase chain reaction. Science 257: 967-971.

Liang S, Rossby SP, Liang P, Shelton RC, Manier DH, Chakrabarti A et al (2001). Detection of an mRNA polymorphism by differential display. Mol Biotechnol 19: 121-124.

Manier DH, Eiring A, Shelton RC, Sulser F (1996). Beta adrenoceptor-linked protein kinase A (PKA) activity in human fibroblasts from normal subjects and patients with major depression. Neuropsychopharmacology 15: 555-561.

Manier DH, Shelton RC, Ellis T, Peterson CS, Eiring A, Sulser F (2000). Human fibroblasts as a relevant model of signal transduction in affective disorders. J Affect Disord 61: 51-58.

Miller AH, Pariante CM, Pearce BD (1999). Effects of cytokines on glucocorticoid receptor expression and function. Glucocorticoid resistance and relevance to depression. Adv Exp Med Biol 461: 107-116.

O'Connor TM, O'Halloran DJ, Shanahan F (2000). The stress response and the hypothalamic-pituitary-adrenal axis: from molecule to melancholia. Q J Med 93: 323-333. 
Pariante CM, Pearce BD, Pisell TL, Su C, Miller AH (2001). The steroid receptor antagonists RU40555 and RU486 activate glucocorticoid receptor translocation and are not excreted by the steroid hormones transporter in L929 cells. J Endocrinol 169: 309-320.

Polentarutti N, Bottazzi B, Santo E, Blasi E, Agnello D, Ghezzi P et al. (2000). Inducible expression of the long pentraxin PTX3 in the central nervous system. J Neuroimmunol 106: 87-94.

Rahman S, Li PP, Young LT, Kofman O, Kish SJ, Warsh JJ (1997). Reduced $\left[{ }^{3} \mathrm{H}\right]$ cyclic AMP binding in postmortem brain from subjects with bipolar affective disorder. J Neurochem 68 297-304.

Ravizza T, Moneta D, Bottazzi B, Peri G, Garlanda C, Hirsch E et al (2001). Dynamic induction of the long pentraxin PTX3 in the
CNS after limbic seizures: evidence for a protective role in seizure-induced neurodegeneration. Neuroscience 105: 43-53.

Rossby SP, Liang S, Manier DH, Chakrabarti A, Shelton RC, Sulser F (2000). Molecular psychopharmacology as a prelude to a molecular psychopathology of affective disorders; the significance of differential display methodology to study programs of gene expression. In: Briley M, Sulser F (eds) Molecular Genetics of Mental Disorders. Martin Dunitz, Ltd: London. pp 31-46.

Shelton RC, Manier DH, Ellis T, Peterson CS, Sulser F (1999). Cyclic AMP dependent protein kinase in subtypes of major depression and normal volunteers. Int J Neuropsychopharmacol 3: 187-192.

Shelton RC, Manier DH, Sulser F (1996). Cyclic AMP-dependent protein kinase activity in major depression. Am J Psychiatry 153: 1037-1042. 